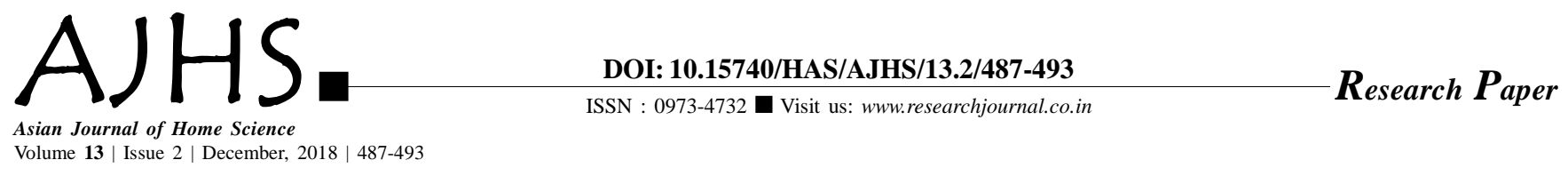

\title{
Adaptive clothing designs of Kurtis for elderly women
}

\author{
Shikha Dashora and Meenu Srivastava
}

Received: 22.03.2018; Revised: 09.10.2018; Accepted: 22.10.2018

See end of the paper for authors' affiliations Meenu Srivastava

Department of Textiles and Apparel Designing, College of Home Science, Maharana Pratap University of Agriculture and Technology, Udaipur (Rajasthan) India
ABSTRACT : The present study was carried out on designing of adaptive clothing designs of Kurtis for elderly women based on their clothing needs to make comfortable dressing for them. The researcher designed 20 different designs of Kurtis with adaptive features which were evaluated by panel of judges on selected parameters in developed rating scale. Findings revealed that the mean scores obtained by all the design codes were found in the higher range, i.e. above 0.66 to 0.91 , which clearly shows that all the developed designs of Kurtis for elderly women were found highly acceptable in terms of aesthetic, functional, constructional and comfort features by the judges.

GEY WORDS: Adaptive, Clothing, Design, Kurti, Elderly, Women

- HOW TO CITE THIS PAPER : Dashora, Shikha and Srivastava, Meenu (2018). Adaptive clothing designs of Kurtis for elderly women. Asian J. Home Sci., 13 (2) : 487-493, DOI: 10.15740/HAS/AJHS/ 13.2/487-493. Copyright@ 2018: Hind Agri-Horticultural Society. 